\title{
Suárez on Visual Perception
}

\section{DANIEL HEIDER}

Faculty of Theology, University of South Bohemia, České Budějovice Institute of Philosophy, The Czech Academy of Sciences, Prague Daniel.Heider@seznam.cz

\begin{abstract}
This paper surveys the main issues in Suárez's theory of visual perception, which in its complexity and systematical ordering has not been explored yet. These questions, exposed in the first five questions of the seventh disputation De sensibus exterioribus in particulari of Suárez's Commentaria una cum quaestionibus in libros Aristotelis and in the first two sections of the fifth disputation De potentiis cognoscitivis in communi, are the following: 1) the nature of light; 2) the nature of colour; 3) the formal (adequate) object of vision; 4) the necessity and the nature of the visual species; 5) the critique of the theory of extramission; and 6) the organ of visual power. The main emphasis is laid on the presentation of the systematical dimension of Suárez's visual theory.
\end{abstract}

Keywords: light; colour; visual species; extramission; Aristotle.

\section{Introduction}

Like any theory of visual perception, Suárez's doctrine of seeing consists of a large body of doctrines ramified into many philosophical and scientific disciplines such as optics, epistemology, psychology, ontology, physics, physiology, anatomy and, to a small extent, geometry as well. ${ }^{1}$ In its psycho-ontologi-

1 This study is a result of the research funded by the Czech Science Foundation as the project GA ČR 14-37038G: "Between Renaissance and Baroque: Philosophy and Knowledge in the Czech Lands within the Wider European Context”. 
co-physical core, Suárez's visual theory is found in the first five quaestiones of the seventh disputation of his Commentaria una cum quaestionibus in libros Aristotelis "De anima" (further: DA VII), ${ }^{2}$ in which the Jesuit ex professo deals with the five external senses (De sensibus exterioribus in particulari). Besides $D A$ VII, topics bearing on the subject of visual theory are presented in $D A \mathrm{~V}$ and $D A$ VI. The explicit subjects of $D A \mathrm{~V}-\mathrm{VI}^{3}$ - discussing cognition and sense perception from a general point of view - are the following issues related to the theory of external senses: necessity and nature of the impressed sensible species (species sensibilis impressa), nature and (co)principles of the cognitive act, nature of the terminus of cognitive act (the so-called species expressa), sensory (inchoative) judgment, typology of sensibles, production of sensible species (the problem of sensus agens), (self)consciousness of external senses, organic "root" of sensation and the question of animal spirits (spiritus animales), veridicality of the external senses. ${ }^{4}$ Setting aside the issues related to general theory of cognition as such, which can be regarded as the "preambula" of the visual theory proper - only the consideration of the question of the integral principles (causes) of the perceptual act would make our treatment of visual perception complete, indeed ${ }^{5}$-, the core issues expounded in $D A$ VII, 1-5 are as follows: the nature of light and color; their bearing on the issue of adequate object of vision; the query whether seeing proceeds by means of the extramission of visual rays from the eyes to the sensibles, or via the intromission of the representatives of the sensibles; the organ of visual perception. All these topics can be considered to be part of the large corpus of issues constitutive of Suárez's visual theory.

In order to present Suárez's theory of vision, namely the external conditions and the internal constituents of perceptual organs as integrally as possible, I will focus just on the core of his teaching in the first five questions

I will quote from the critical edition: Suárez 1981, vol. 2, ed. Castellote.

While $D A \mathrm{~V}$ is called "De potentiis cognoscitivis in communi" (282-451), DA VI is titled "De sensibus in communi” (452-545).

4 For the analysis of the various aspects of the general theory of external senses see South 2001.

5 I have already treated the issue of Suárez's “cognitive activism” elsewhere. See Heider, 2015; 2016 a, 38-66, esp. 47-52; cf. also 2017 (forthcoming). 
of $D A$ VII and on the relevant aspects of his theory of species visuales from $D A \mathrm{~V}, 2$. These two segments are closely related. My primary goal is to reconstruct Suárez's highly systematic theory of vision from bottom to top, i.e., from the theory of visual objects, i.e., light and color, via the doctrine of species visibilis in medio and in the organ, up to the doctrine of the direction of vision and the visual organ. This exposition of the nodal points of the Jesuit's complex visual theory is a desirable enterprise since as such it has not been elaborated yet. ${ }^{6}$

\section{1."Naturalistic" and Qualitative Concept of Light}

Much like Aristotle in the seventh chapter of the second book of his De anima, ${ }^{7}$ Suárez starts his enquiry into seeing with an analysis of light. When he asks "what the nature of light (lumen) is" he has in mind the light in a transparent medium (the air). By this outline he sets aside light conceived as lux, light inhering in a luminous source such as fire. In his preliminary statement, Suárez declares that light is something real. Light cannot be eliminated as a mere manifestation of colour (coloris manifestatio). We often see light not seeing any colour when we see, e.g., the heavens. Having established that lumen is a real item and having answered the question "An sit?" Suárez comes to the question "Quid sit lumen?". The Jesuit rejects three rival theories. Following Aristotle he first of all turns down the thesis that light is a body (corpus). If lumen were a body, then two bodies (light and the illuminated object) would coexist in the same place. This is an impossible state of affairs at least in the natural order. Moreover, if the effluence of lumen were similar to the egression of corpuscles, light would have to traverse space in time. In the perception of distant objects this "wandering” would become noticeable by the human eye, however. As Aristotle explains in On Sense and Sensible Objects, ${ }^{8}$ this temporal delay, caused by local motion of

6 For the expositions of its partial aspects see Knuuttila 2015, 205-6 and Castellote 1962, 145-150.

7 Aristotle, On the Soul, 2000, book 2, ch. 7, 418b3ff, 105.

8 Aristotle, On Sense and Sensible Objects, 2000, ch. 6, 446b26-447a12, 269. 
light, cannot be attributed to light since all the parts of the medium lying between the luminous body and the organ of the percipient are affected in an instant (DA VII, 1, vol. 2, 552-4).

Having dismissed the corpuscularian account Suárez comes to disclaim the view that light is the substantial form of the sun. As the Jesuit avers in $D A$ IX, 4, no substantial form can be sensed per se. Substantial form is not sensible per se but only sensible per accidens (DA VII, 2, vol. 2, 554). Rejecting the first two competing theories, Suárez arrives at the opening conclusion: "Light is an accidental act pertaining to the category of quality" ["Lumen est actus accidentalis ad praedicamentum qualitatis pertinens."] (DA VII, 1,3 , vol. 2, 554). As an accident light must inhere in its subject, namely in a translucent medium, which is penetrable by light throughout.

What kind of quality is light? On one of the influential sentiments (actually the third one denied by Suárez) lumen is the intentional species of lux. Accordingly, light cannot be a physical quality since its properties are identical with those of the intentional species. Like the sensible species, by virtue of which we perceive sensibles while not seeing the species themselves, we perceive the sun through sunlight without seeing light itself. Light thus does not constitute the per se visibile but only that, by which (quo) we apprehend the sensible object and not the object (quod) of our vision. Moreover, light has to be of spiritual nature since colours, transferred from the sensibles to sight, do not have natural (physical) being but only intentional or spiritual being. They do not interfere with each other. The upshot of this reasoning seems to be as follows: Rather than a physical entity light is a more subtle entity, which is nobler than the physical sensible quality, having spiritual and immaterial being. Suárez is not impressed by this argument, which draws from the metaphysics of light present in the Neoplatonist tradition. He makes clear that all the analogies between the intentional species and light are only virtual since lumen is a quality having natural and true being. "Lumen est qualitas habens proprium esse naturale et reale.”] (DA VII, 1, 8, vol. 2, 558). Contrary to the intentional species, light is the object of seeing. Unlike the intentional species, light denominates its subject. We say that the sensible object, say Peter, is illuminated while we do not say that Peter who sees the 
green colour turns green. Moreover, light cannot be a spiritual entity since it has material effects such as heating and drying (DA VII, 1, 6, vol. 2, 558).

Suárez's "naturalistic" concept of lumen is underlined by the third conclusion which has three parts: 1) The light of air is a quality which can be seen as an object (terminus); 2) the light is not visible per se but through its species; 3 ) the sensible species is not the species by which we see the sun. ["Lumen aeris est qualitas visibilis, quae videtur tamquam obiectum visus; et non videtur per se, sed per species sui; neque etiam est species per quam sol videatur."] (DA VII, 1, 9, vol. 2, 560). First, it is a part of our experience that we perceive light in a different "quality" when we see it brighter at noon and less bright at twilight. Second, after the vision of light the species of light remains in the phantasy. So later on we are able to know light in the abstractive way, i.e., in its absence. This shows that the visual species of light is impinged on sight. Third, the species of light is not directed to the cognition of the sun since it is not its formal likeness. Not differently from heat, light is a communication of the luminary source. If light were the species through which we perceive the sun, it would have to be said that, once illuminated, our sight would necessarily see the sun, which is not the case. Concluding, it may be said that for Suárez lumen is a natural (physical) quality inhering in a translucent subject. It does not radiate in the manner of material effluence of corpuscles by means of local motion, but only by means of (instantaneous) qualitative change in this subject.

\section{Colour as a Real Quality}

Suárez's discussion of the ontology of colours shows that the issue of the ontological status of colours, so typical for both early modern discussion in general and the contemporary discussion in analytical philosophy, ${ }^{9}$ was "a hot issue" for the Jesuit as well. At the same time it displays that the status

9 For the early modern and the contemporary discussion among physicalism (the qualitative aspect of colour of which we are conscious is a physical quality of sensibles), dispositionalism (the qualitative aspect of colour is a disposition of sensibles to produce certain colour experience) and subjectivism (the qualitative aspect of colour is exemplified by perceivers) see Ross 2015, 411-9. 
quaestionis of $D A$ VII, 2, in which the question is ex professo treated, can be seen as similar to that formulated by the philosophers of the nominalist lore in the late medieval philosophy of the $14^{\text {th }}$ century. ${ }^{10}$ Suárez's "Fragestellung" in the second question of $D A$ VII is marked by a reductionist view of colours. On this concept colours are nothing but structural properties having quantitative characteristics such shape, structure, etc., at the surfaces of opaque bodies, which account for the ways in which light is reflected to the percipient. On this view, colours are nothing above the light reflected by the surface of the opaque body to the percipient. Accordingly, ontologically speaking, there is no essential difference between lumen and colours. The manner of reflection at the surface of the body correlates with the perception of a particular colour. ${ }^{11}$ Although this position is notoriously taken to be one of Descartes's views of colours - no doubt the less idealistic than his other views $^{12}$ - this account is not, as Anneliese Maier shows (Maier 1963, 3-32), without its medieval antecedents. It was Nicole Oresme (c.1320-1382) who can be regarded as one of the potential medieval advocates of this opinion. Accordingly, colour as such is construed in terms of the dispositional properties of the object causing sensation in us (DA VII, 2, 1, vol. 2, 570).

Albeit Suárez does not abandon the basic position according to which colours are grounded in light, he is far from reducing colour to the quantitative (dispositional) properties of the surfaces of visible objects: "Colours are real and permanent qualities inherent in coloured bodies, even though these bodies are not illuminated" ["colorem secundum substantiam suam

10 For the issue of the nature of light and colour and their interrelation in late medieval nominalism see Lindberg 1976, 133-7.

11 On the modern physical theory, the reflected light can be separated into two components, namely into a diffuse component and a specular component. While the light in its first component is reflected form the surface at many angels, and thus it displays relatively little dependence on the angle between the light source, the object's surface and the eye, the incident ray in its second constituent comes from a single incoming direction and is reflected into a single outgoing direction. Unlike the first, the second reflection is more mirror-line and highly directional. Accordingly, if we take into account the second component, it may be said that the same surface can potentially give rise to different perceptive qualities in two different perceivers. For this distinction between these components in the reflected light, see Hilbert 2015, 259.

12 For three different theories of colour in Descartes, see Wolf-Devine 1993, 44-49. 
esse qualitatem permanentem in corpore colorato, etiam si non illuminetur, resultantem in illo ex mixtione elementorum.” (DA VII, 2, 2, vol. 2, 572). The view that Peter ceases to be a white man at sunset sounds incredible to Suárez. Colours are not visible in the dark, indeed. In order to be visible they need to be illuminated. But their visibility, a property of colours, is something different from their ontological status. As the argument from variability and invariability shows, they differ from light since the sensation of the white colour can remain identical while light changes. The gradual lack of light at sunset can be compensated by an approximation of the percipient to the coloured body. The variation of the former and the invariability of the latter point to their ontological difference (DA VII, 2, 3, vol. 2, 574).

If colour is a permanent quality of objects and provided that it originates from a mixture of elements in the body, how does the mixture, i.e., secondary quality, look like? In his exposition Suárez notes that beside the primary qualities of Cold, Warm, Dry and Moist, which in different proportions constitute the four basic elements, sc. Water, Earth, Fire and Air, the elements can also be classified according to the degree of their diaphaneity. While Fire represents the lucid factor or a luminary source, Earth represents the contrary aspect, i.e., opacity. While Fire is the active source of illumination, the element of Earth impedes its action. The other two elements, Water and Air, are the factors, which are entirely penetrable by light. The more the mixture has of Air or of Water, the more it participates in diaphaneity and the more it disgregates sight. Conversely, the more it possesses of Earth, the more it tends to be opaque and the more it congregates sight. Since each resulting mixture is always composed not only of one element, namely of Earth, but also of other elements, it retains, in greater or lesser degree, traces of diaphaneity as well. Suárez stresses that the Fire inherent in the body, more or less "choked" by the opacity of the Earth in the body, does not persist in the mixture formally qua Fire. In fact, it is transformed to a new ontological quality, which is colour (DA VII, 2, 3, vol. 2, 574-8). Concluding, colour is a secondary (in the scholastic, not early modern, sense) quality which is the act of a mixed body inasmuch as it has perspicuity limited (damped) by opacity (DA VII, 2, 3, vol. 2, 578-580). 


\section{Adequate Object of Vision}

In Aristotelian-scholastic philosophy colour as the proper sensible object of sight is at large deemed to be the formal or the adequate object of vision. ${ }^{13}$ Colour seems to be widely regarded as the total object of sight. Strictly speaking, this claim is not the position of Suárez (DA VII, 3, 7, vol. 2, 596). It has been stressed that for Suárez sight can see not only colours but also light - light constitutes the terminus of sight. [“[...] obiectum adaequatum visus esse lumen et omne quod lumine manifestatur, seu res illuminata ut sic.”] (DA VII, 3, 7, vol. 2, 596). Following Aristotle, ${ }^{14}$ Suárez refers to a group of visible colourless things such as fire and stars called lucid things (res lucidae). The object of sight is not only colour but also the light of res lucida. Lumen is not only the medium through which we see, but no less also an object of vision (DA VII, 3, 1, vol. 2, 586-8).

Suárez proposes two upshots, which both shed light on the nature of the interrelationship between visibles (light qua the object of vision and colours) and light conceived as via from the power to the sensible. In the first conclusion he affirms that lucid things, as a special category of visible objects, do not require as a necessary condition both the prior illumination and the presence of light in the medium since they can be seen through their own light (DA VII, 3, 2, vol. 2, 588). Lucid things generate twofold activity, namely they diffuse lumen and the visual species (DA VII, 3, 2, vol. 2, 590). Accordingly, it may seem "logical" that they themselves at first illuminate the medium, through which they (can) multiply their visual species and only thus the lucid things as such become visible. At variance with this position, Suárez asserts that their illumination of the medium is far from necessary for their visibility. The eyes of a cat whose light is so weak that it can hardly illuminate the whole medium incident between it and the percipient, can be seen in the darkest night. Moreover, Suárez admits the possibility that the visual species can be diffused further than the real entity of light, which in

13 For this claim cf., e.g., Thomas de Aquino, Summa theologiae, 1888, I, q. 1, art. 3, co., 12.

14 Aristotle mentions fungi, flesh, heads, scales or eyes of fishes. See On the Soul, 2000, book 2, ch. 7, 419a5-7, 107. 
fact can be seen only by virtues of its visual species. As less perfect entities (more on this see in Part 5), the visual species of light can attain the more remote places than light itself ( $D A$ VII, 3, 3, vol. 2, 590). ${ }^{15}$

Although actual illumination of the medium is not necessary for colours to be colours in $a c t u$, in order to be visible they must be illuminated. ${ }^{16}$ In the first part of the second conclusion, Suárez claims that contrary to the aforesaid lucid things colours must be illuminated per se. Without being illuminated they cannot emit their visual species. Even though colours as such are visible, they are visible only "remotely". In order to become visible "proximately" they must be lightened beforehand. However, albeit this per se illumination of colours themselves is necessary, this does not hold for the medium. In the second part of the conclusion, Suárez says that it is not necessary for the medium to be illuminated per se, it is enough for it to be illuminated only ex consequenti. What does this phrase mean? I take Suárez saying that the illumination of the medium is only the consequence of the illumination of the visible. If the sensible is lighted, then also its immediate surroundings have to be illuminated as well. While the first illustration is the necessary condition as far as the first stage of the production of visual operation is concerned, the second illumination is not inevitable. Next, clearly, if Suárez admits this dispensability of prior light in the medium, all the more he has to grant it in the case of illumination of the visual faculty itself ( $D A$ VII, 3, 4, vol. 2, 590-2). As spectators in the theatre we know well that we can perceive actors while being in total darkness.

\section{Visual Species}

It has been said that lucid things as natural agents generate twofold operation, namely the illumination of the medium and the emission of visual

15 This further reaching emission of the sensible species holds for the audible and the olfactory species as well. For hearing see $D A$ VII, 8, 7, vol. 2, 670-2; for smell see DA VII, 3-4, vol. 2, 702-6. It is also one of the main reasons why to posit the sensible species in the external senses.

16 Strictly speaking, visibility can be taken as the property of colours. 
(impressed) species. It was also conceded by Suárez that the visual species can be multiplied to a distance going beyond that of light. The claim about the natural efficacy of the species is developed in $D A \mathrm{~V}, 2$, where Suárez explicitly deals with the issue of the nature of the sensible species, which is essential for any explanation of the principles of a perceptual act. ["Unio obiecti cognoscibilis cum potentia est necessaria in omni cognitione.”] (DA V , 1, 3, vol. 2, 286) Much like in case of light also here before asking “Quid sit?” Suárez approaches the issue “An sit?”.

His argument for the existence of the sensible species, a claim targeted against Ockham and his action at a distance, ${ }^{17}$ is basically twofold. While the first one is based on a priori reasoning, the second one is an a posteriori argument. On the first way of arguing Suárez starts from the axiom of broadly conceived Aristotelian cognitive psychology. On this axiom, cognition proceeds by means of assimilation of the cognizant to the thing known. The known thing must be, as it were, dragged into the percipient. Clearly, a sensible cannot be pulled into a cognizant in its real being but only by means of its intentional proxy, i.e., by means of the sensible species, which can be either the thing's real form (without matter), as it is the case in Aristotelian-Thomistic philosophy in general, or the (virtual) representation of the sensible (Suárez's own stance). Besides, the external senses in themselves are indifferent to cognition of this or that sensible object. In order to revoke their neutrality, they must be determined intrinsically. The neutrality of the cognitive power must be revoked only via intrinsic determination, namely via the visual species ( $D A \mathrm{~V}, 1,5$, vol. 2, 290-2). According to one of more experientiae, which are to substantiate the existence of the sensible (visual) species, it holds that we have to posit the visual species since it is the only available explanans of the situation, in which Peter standing in front of a mirror sees in the mirror an object located behind him. Peter can see it due to the mirror's reflection of the visual species of the object $(D A \mathrm{~V}, 1$, 4 , vol. 2, 288).

17 For Ockham's denial of the intentional species see Tachau 1988, 133-4. 
The aforesaid affinity of the sensible species with lumen leads Suárez to two conclusions, which constitute half of the overall quaternion of propositions on the issue of the nature of sensible species. If lumen in medio is an accidental form, namely a quality inhering in the air, the visual species must be an accident of quality as well ( $D A \mathrm{~V}, 2,2$, vol. 2, 296). Much like lumen is not a particle that moves locally from the luminous source to the visible object and then is reflected to the percipient, so the sensible species cannot be an "Epicurean" eidolon, ${ }^{18}$ as caricatured by Descartes in his first chapter De la lumiere of his La Dioptrique, which "flies" as a material picture in the air from the visible object to the eyes. ${ }^{19}$ Its "transfer" must occur instantaneously. In a link to perspectivi, Suárez says that this species is linearly multiplied in all directions, i.e., circularly, from all sides of the visible object. Like light inhering at first in the luminous source (lux) and then in the translucent medium (lumen), so the sensible species at first inheres as an accident in the substance and then as an accident in the illuminated medium, from which potentiality it is multiplied. Rather than pertaining to the kind of quality called figura the visual species belongs to the kind of disposition ( $D A \mathrm{~V}, 2$, 23 , vol. 2, 324). The essentially accidental character of the sensible species of the external senses is confirmed by the ontological dependence of the sensible species on the sensible qualities of the material substance. At least in the natural order, the sensible species depends on those objects both in their fieri and conservari (DA V, 2, 2, vol. 2, 296). ${ }^{20}$

The physical character of light finds its systematic counterpart in Suárez's second conclusion. Contrary to the intelligible species, the sensible species is fully material and divisible ( $D A \mathrm{~V}, 2,17$, vol. 2,316$)$. It is not improper to say that the explicit refusal of the spiritual character of

18 For the passage, where Epicurus characterizes his eidolon see Miira Tuominen 2014, 44-5.

19 “... petites images voltigeâtes par l'air, nommées des espèces intentionales, qui travaillent tant l'imagination des Philosophes", René Descartes, La Dioptrique, 1902, Discours 1, 85.

20 I am leaving aside the issue of the possibility of divine intervention, in which God can cause in us the perception of an absent object, i.e., the kind of abstract cognition. If it holds that the sensible species is the absolute entity generating efficient causality, it has to be, in principle, substitutable by the divine causal intervention. For this see $D A$ VI, 5 , 516-528 and also Heider 2016b, 173-203. 
sensible species can be seen also in the context of Suárez's indirect critique of Aquinas's notion of visual species. Without delving into Aquinas's theory and the detailed comparison of the conceptions of both authors, which would require another study, it must be said that as compared to the Jesuit Aquinas is obviously more inclined to "spiritualization" of the sensible species, as he seems to be in case of light too. ${ }^{21}$ If lumen and the proper organ of the visual power, namely the pupil, is corporeal, the sensible species must be material as well. It does not make much sense to say that a spiritual species is received in a material subject. In harmony with its materiality, Suárez also refuses the theory, which takes the natural and the intentional (spiritual) sides of the sensible species to be really distinct aspects of the sensible species. ${ }^{22}$

Although material and divisible, it is not of the same kind as sensible objects ( $D A V, 2,8,306)$. In a critique of Durandus of Saint-Pourçain (1275-1332 or 1334), ${ }^{23}$ Suárez avers that they are specifically (speciei) different. Contrary to light, the species cannot be the object of our perception. If the visual species were the immediate object of sensation (we would get a representationalist theory of perception), it would have to be of the

${ }^{21}$ For the sample of Aquinas's statements going in this "spiritualizing" direction see the following: "Corpus enim naturale recipit formas secundum esse naturale et materiale ... sed sensus et intellectus recipiunt formas rerum spiritualiter et immaterialiter secundum esse quoddam intentionale”, Thomas de Aquino, Sentencia libri de sensu et sensato, 1985, tr. 1, 1. 19, n. 11, 99. Contrary to Suárez, Aquinas lays the emphasis on the theory advocating the spiritualizing effect of light, which he considers to be the probable view: "Alii dicunt, quod lux non habet esse firmum et ratum in natura, sed est tantum intentio: sicut enim dicitur, quod species coloris per aerem ad pupillam delata, in aere non habet esse naturale, sed spirituale [...], ita etiam intentio corporis lucidi in relictas est lumen. Et haec opinio valde probabilis est [...] ut dicit Dionysius: ex hoc etiam est quod [lux; D. H.] coloribus esse spirituale confert, secundum quod esse recipiunt in medio et in organo; unde et ipsum lumen virtutem spiritualem habet”, Thomas de Aquino, Scriptum super Sententiis, lib. 2 d. 13 q. 1 a. 3, co. [accessed August 18, 2016]. Available on-line: http://www.corpusthomisticum.org/snp2012.html. As regards the Jesuit reaction in general to this Thomist “spiritualizing” tendency, see Wolf-Devine 1993, 31. For Albert the Great's and Aquinas's immaterial interpretation of the spiritual being of visual species cf. also Knuuttila 2008, 13-4.

22 For Suárez's presentation of this view see $D A$ V, 2, 5-6, vol. 2, 302-6; for the sharp critique of this position cf. $D A \mathrm{~V}, 5,24$, vol. 2, 326 .

23 I cannot entirely share Jörg Telkamp's view that “... Durandus is Suárez's main source, with whom he disagrees only occasionally”. Cf. Jörg Alejandro Telkamp, 2012, 7. 
same kind with the visible object. In his vindication of direct realism Suárez underlines that the species is (at least, non-reflexively) "ignota" ( $D A \mathrm{~V}, 2$, 6 , vol. 2,306$)$. So what we see in the mirror is not the visual species. Nor can it be said that what we actually see in the mirror is the mirror plus the reflected thing in the way that through the single visual species we get the likeness of diverse objects, namely the mirror and the mirrored thing. In his anti-representationalism, Suárez asserts that through the species we see in the mirror an external object itself ( $D A \mathrm{~V}, 2,16$, vol. 2, 316).

In his last conclusion, Suárez comes to assert that the materiality of sensible species does not mean that the species is not the formal likeness of sensibles ( $D A \mathrm{~V}, 2,21$, vol. 2, 322). Sensible species does not pertain to a higher and nobler ontological place in the hierarchy of being than its "parental" object. In order to be produced it does not need an "ontological elevator" such as a separated intelligence or God who would transform the sensible quality to intention which could be received by sight (DA VI, 2, 3, vol. 2, 470-2). This transformation is not made by the illuminated medium either. It comes to exist only by virtue of the sensible quality itself. The visual species is the trace (vestigium) or imperfect participation of sensible quality. It does not require a higher cause concurring in the production of the intention in the medium and in the organ. The heat produced in my hand by fire is of higher perfection than its species (DA VI, 2, 6, vol. 2, 474-6).

\section{5. "Direction" of Vision and Spatial Perception}

Even though Suárez considers the reception of the visual species to be the necessary first stage in the origin of a visual act, there is still the query, typical for visual theory since the days of Plato, whether the act of vision proceeds only by so-called intromission (reception) of the sensible species, or also by so-called extramission of the visual (animal) spirits or rays. According to Plato, Galen, ${ }^{24}$ and others vision does not run by the mere

24 Timaeus, 1925, 45b-d; as regards Galen, see Siegel 1970, 46-7. The fact is in Theaetetus Plato does not deny that the visual species come from the object to sight (see Theaetetus, 1921, 156e). 
reception of something from the outside but rather by the emission of the visual rays from the eyes (being of fiery disposition rather than of watery temperament) toward the visible object. ${ }^{25}$

In his typology of various versions of the extramission doctrine Suárez moves very systematically. ${ }^{26}$ There are two main versions (each having two subvariants) of this doctrine. While one can be called the non-reflexive version, the other can be termed the reflexive variety. On the first sub-version of the first kind the visual spirits, due to the pneumatic tension in the eyes, emanate from the eyes and by altering the medium they attain the visible object itself, in which the spirits intermingle with the visual species emitted from the sensible object. Without coming back to the eyes they constitute the vision itself in the presence of the visual object. On the second subvariant, espoused by the Spanish physician Francisco Vallés (1524-1592), ${ }^{27}$ the visible object at first emits the visual species up to the eyes, where the visual spirits get mixed with them. When the visual spirits connect with daylight, the air, due to this alteration, acquires the capability to see. Much like an extrapolated optical nerve the point in the air becomes a sort of prosthesis of the eyes. Accordingly, the air becomes "sentiens" and the human acquires sort of a second visual organ in the air. ${ }^{28}$ On the second main version, there are again two alternatives. When the eyes emit the light or the visual spirits to the visible object, they blend with the visual species of the object and return to the eyes to produce the act of vision there. On the second sub-version of this reflexive approach, the visual spirits do not attain up to the visible object but mingle with the visual species somewhere in the

25 For an excellent exposition of this account in Plato and his forerunners, see Lindberg 1976, 3-6.

26 For the illustrative scheme of these versions see Castellote 1962, 147.

27 For Vallés, the important reference for Suárez, see Castellote 1963.

28 "Multiplicari a coloribus species eiusdem naturae cum illis usque ad pupillam oculi, $\&$ rursus exire animales spiritus usque ad externam superficiem pupillae, \& illinc lumen quoddam coeleste, eiusdem generis cum lumine solis, quod solum per se non potest illustrare aerem, cum externo lumine coire ... Iuxta quam sententiam recipit aer influxum virtutis videndi illustratione illa, non aliter quam nervus, \& ita est nobis aer pro medio coniuncto, in quo videmus. Visio itaque unica agitur in aere \& oculo. Haec enim duo media unum fiunt. Unde constat quodammodo, aerem esse sentientem, quia videmus per aerem", Valles 1556, lib. 2, cap. 28, 106-7. 
medium. Only from that point in the medium they come back to the eyes, where vision gets located ( $D A$ VII, 4, 1, vol. 2, 600-4).

In direct link to Aristotle, ${ }^{29}$ Suárez reproves all the versions of extramission in favour of the intromissionary account. At least in its first stage, vision proceeds only by means of reception of the visual species (DA VII, 4, 2, vol. 2, 604). Four arguments are presented on behalf of this conclusion. First, the visual rays are redundant. The impressed species emitted from the sensible objects through the air and received in the attentive cognitive power is all we need for the elicitation of vision. No emission of visual rays or spirits proceeding from the eyes outside is necessary ( $D A$ VII, 4, 2, vol. 2 , 604). Second, what actually are these visual spirits? They can be neither substances nor accidents. If they were substances, they would have to be either generated de novo in the air, or they would come to be through the local movement from the eyes. The first alternative is impossible since every substantial generation entails the corruption of the preceding substance, which in this case would be the air. This corruption is at odds with our experience, though. The second option is even less plausible. If the visual rays were "flying" in the air, vision would have duration, which runs afoul with the instantaneous character of vision. Moreover, during sunny days the more tenuous visual rays would have to be eliminated by the more intense light (DA VII, 4, 2, vol. 2, 604-6). Third, the non-reflexive version of the extramission theory is at variance with the essentially vital and immanent character of sensation. It is absurd to say that the air as a soulless entity could see (DA VII, 4, 3, vol. 2, 608). Fourth, it does not make sense to say that the visual rays come only to a certain point in the medium from which they return to the eye. If there is no impediment in the medium, no such a reflection in this point is possible. The emission of visual spirits from the eye is not a free action ( $D A$ VII, 4,4 , vol. 2,610 ).

Despite the number of arguments against the theory of extramission, as Suárez shows, Vallés argues for the theory of extramission on the different

29 For Aristotle's criticism of the theory of extramission see De sensu et sensato, cap. 2, 437b13 5: "[...] if vision occurred when light issues from the eye as from a lantern, why should not vision be equally possible in the dark?”. 
basis, namely by referring to what can be regarded as the blind spot of the Aristotelian tradition in general. It is the perception of size and distance of visible objects, which are commonly rated to be the common sensibles. ${ }^{30}$ Although Aristotelians usually mentions explicitly only five of the common sensibles, besides size it is figure, number, quiet, and movement, Suárez adduces also distance, and says that it is reducible to size. As he says, distance is the size actually or potentially inserted between two things (DA VI, 1 , 9, vol. 2, 462). But how can there be an intention of such relational thing as distance in the visual species? On Vallés, Aristotelians actually cannot explain this issue. As ridiculous he rejects the view that there is a special visual species of distance. No less he denies the claim that distance is perceived by means of the same species as colour but by some modification of the species of the proper sensible. He makes clear that neither the perfect nor the attenuated species can cause the vision of proximity or distance. These species can cause at most more or less perfect seeing of colour. He concludes that size and distance can only be seen if the faculty "steps out" through the air to the visible thing itself. Only when meeting the visible object can the faculty "measure" the distance and size of the object. ${ }^{31}$

In his reply to Vallés the Jesuit agrees that the size of the sensible object is seen neither through the size of the visible species - the small species represents a high mountain - nor by virtue of a special species. Nevertheless, with reference to $D A$ VI, 1 , Suárez explains that size and distance are represented as modifications of the visual (proper) species. Despite this conclusion, which is part of the Aristotelian tradition, Suárez considers the issue of spatial perception to be "a hot issue". However, it is not controversial

30 On different models of spatial perception including the modern ones of Descartes and Berkeley see Yrjönsuuri, 2014, 187-206. The doctrinal swing to the theories of extramission motivated by the issue of spatial perception can be seen also in contemporary discussion. For extramissionist theories and spatial perception see Hilbert 2015, 259-260.

31 Vallés 1556, lib. 2, cap. 28, 106: “... (si nihil de oculis prodiit ad rem videndam) non aliter potest videri [proximity; D.H.], quam aut specie alia, aut illius eiusdem speciei modo alio. Sed horum alterum est ridiculum: alterum falsum ... intensior species intensum videri faciet colorem, non propinquum: remissior remissiorem, non distantiorem"; ibid. 107: "Visio itaque fit intrantibus speciebus, quo colores sentiantur, \& afficiantur proprium visus instrumentum: \& facultate exeunte ad dimetiendum distantiam \& magnitudinem”. 
only for Aristotelians but also for Galenists. Considering Valles's version of the theory of extramission Suárez notes that with respect to the query of how we perceive distance this theory has the following demerit: how to explain the perception of the distance, which remains between the point in the air where the vision is terminated and the visible object itself? If Vallés denies the theory embraced by Suárez, namely that the distance and size of the visible object is perceived by means of a modification of the visual species, it is Vallés, not Suárez, who has to carry the onus probandi in the explanation of the issue how to understand the spatial perception (DA VII, 4,7 , vol. 2, 614-6).

If the only plausible explanans of the perception of size and distance is by modification of the visual species of the proper sensible, how does Suárez precisely understand it? Within his intromissionary account Suárez at first offers a traditional account of why things appear to us bigger or smaller. According to the common view of perspectivi and Aquinas, ${ }^{32}$ the reason why objects appear to us to be bigger or smaller is the size of the angle formed by the visual species sent forth from the visible objects. According to this theory, which is called the doctrine of visual cone (pyramid), visual species are emitted from the visible objects in the form of a pyramid, the base of which is the visible object and its vertex is the eye. The longer are the lateral sides of this cone, the lesser angle we get. Provided that this reduction of the visual angle obtains in case of the same object, it is clear that this object appears to be smaller and becomes more distant than before. It is also identity in the size of the angle at the vertex of the cone what explains why we perceive objects of different size as identical ( $D A$ VII, 4,8 , vol. 2, 616).

32 Thomas de Aquino, Sentencia De anima, lib. 2 1. 15 nn. 8-9, 133-4: “... omne corpus videtur sub quodam angulo cuiusdam trianguli vel magis pyramidis, cuius basis est in re visa et angulus est in oculo videntis ... cum res visa sit maior quantitate, quam pupilla, oportet quod proportionaliter diminuendo pervenit immutatio visibilis, usque ad visum; manifestum est autem, quod quanto latera trianguli vel pyramidis sunt longiora, dummodo sit eadem basis, tanto angulus est minor, et ideo quod a remotiori videtur, minus videtur, et tanta potest esse distantia quod omnino non videtur". Clearly, this mathematical approach has its roots in Euclidean geometry. For the ancient roots of optical geometry see Lindberg 1976, 11-7. 
Despite the common plausibility of this view Suárez does not share it entirely. He is sure that at a certain distance the variation of the visual angle does not have any impact on the perception of size. At least within a certain medial distance the visible object is seen as identical in size regardless of any shift in its angle. Moreover, if we adhered to the theory of the visual cone we would have to say that doubling the distance of an object necessarily entails reduction of its size to half. However, this reciprocal proportion does not cohere with our experience. Furthermore, on the aforesaid theory, things perceived under the same angle will always appear to be of the same size. Consequently, a small thing standing in the proximity of the percipient and a large remote thing will appear to be of the same size since both will result in the description of the same angel in the percipient. However, this seems to make sensory perception an overly fallible instrument ( $D A$ VII, 4, 9, vol. 2, 618). Contrary to Vallés, Suárez thus recurs to the theory, which he considers to be the only one at hand. Within a certain distance the visible object is capable of producing a perfect likeness of itself. Thus it is apt to represent perfectly the size of the object of which it is the visual species. However, beyond a certain distance the formal likeness, emitted by the object, fades out and sight can elicit only an imperfect perceptual act. It is only because of the reception of this imperfect visual species that the visible object will always appear to be smaller. Mutatis mutandis, distance is perceived in the same way as well. It is not difficult to cognize the distance of an object perfectly imprinting its species in the visual power. If the likeness of the object and its impression is less perfect, which is often caused also by the quality of the medium (vision at sunset, e.g.), the object is cognized as more remote ( $D A$ VII, 4,11 , vol. 2,620$)$.

\section{The Organ of Vision and "Double Vision"}

While in DA VII, 4 the medical tradition, represented by the names of Galen and Vallés, constituted largely the negative point of reference, in DA VII, 5 where the Jesuit approaches the subject of the anatomy of the eye this tradition is for him of crucial authority. Not Aristotle but Andreas Vesalius 
(1514-1564), the Dutch anatomist and physician, is to be followed in the matters of assignation of the proper organ of visual faculty. It was not Aristotle's fault that his views of the visual organ and its root are outdated. It is the demerit of the time in which he lived (DA VII, 5, 2, vol. 2, 624). One of Suárez's main corrections of Aristotle's statements consists in his refusal to locate the principle of sensation in the heart. The "root" of sentiendi lies in the brain ( $D A$ VI, 6, 6, vol. 2, 534). However, even though the title of $D A$ VII, 5 - "Quodnam sit et quale organum potentiae visivae et potentia ipsa" - is formulated in physiological terms, the framework of the query is articulated in the psychological way, namely why is there, phenomenologically speaking, only one seeing, and not two, if the eyes are two. ${ }^{33}$

The Jesuit indicates that answering this question requires a brief account of the anatomy of the human eye, which he takes from the second book of Vesalius's De fabrica corporis humani (1543). The substance of the eye having an oval shape contains five tunics, three humours and seven muscles. Passing over the names of the muscles Suárez provides the reader with the names of the humours and tunics. In the centre of the oval substance there is the pupil consisting of the colourless crystalline (glacial) humour. This transparent liquid is served by two surrounding humours, namely by the vitreous and by the albuminoid humour. At the same time it is also assisted by five tunics: the innermost tunic is the arachnoid membrane, there follows the recticular membrane, the uvea tunic, the cornea and the outer conjunctive layer ( $D A$ VII, 5, 1, vol. 2, 620-4). Further, there are two optic nerves, one is right, the other is left. While the left originates in the left part (hemisphere) of the brain, the right descends from the right part. Both optic nerves are channels through which the animal spirits go from the brain and assist in the production of vision - this also why the brain injury affects the external sensation proper. Both nerves intersect and create what anatomists call the optic chiasma (DA VII, 5, 7, vol. 2, 630). As Suárez shows, for some medieval authors - Avicenna and Albert the Great - the proper organ of vision or the

33 Descartes and also contemporary authors were well aware of this problem. For Descartes see Wolf-Devine 1993, 59; as regards the stereoscopic vision in contemporary debate see Hilbert 2015, 263-4. 
final sensorium was precisely this chiasma. According to them we can have unique vision only because of this intersection. If the pupil, and not this intersection, were the organ of vision, we could not have one but only two visions ( $D A$ VII, 5, 8, vol. 2, 630).

Suárez does not sympathize with this view. Following Galen he declares that the pupil is the proper organ of the visual power. He brings in two arguments. One is based on the substance of the crystalline humour. The adequate organ of the visual power must be the crystalline humour since precisely this matter, and not any other coloured stuff, is most suitable for the reception of the visual species. The glacial humour is soft, diaphaneous and colourless. If it were, say, black, it could not receive the white colour. The black colour would prevent it from the reception of the white colour much like bitter coating on the tongue affects our tasting of honey. As such the glacial humour is ideal for the reception of colours because the perceiving power must be deprived of the nature of its object. ${ }^{34}$ The second argument comes from medical experience. If the pupil is irrecoverably injured, vision is irrecoverably impaired as well. This does not always obtain if the other humours and tunics are impaired (DA VII, 5, 3, vol. 2, 626).

However, if the optic chiasma is not the proper organ of vision, for what is it instituted by nature? On Suárez the intersection of the optic nerves is ordained by nature not for getting unique vision but for a different reason, namely for a certain compensation. In case one eye is impaired and a man becomes single-eyed, the optic chiasma will insure that the animal spirits flowing from the brain normally to both eyes will get in the higher degree to the second (healthy) eye, by which the power of the healthy eye will be strengthened in its vision. Moreover, it is not true that if the proper organ is the pupil we must get two visions. If our eyes have the same position (situs) - and one does not have the concave shape while the other has the convex one -, which they normally do, they will be equally affected by the visual species. Only in the rare and abnormal cases when there happens to

34 Aristotle, On the Soul, 2000, 418b26-7, 165: "It is the colourless which is receptive of colour, as the soundless is of sound." 
be an inequality in the positions of the eyes, a single thing will appear to be double (DA VII, 5, 9, vol. 2, 632).

\section{Conclusion}

An important formal feature of Suárez's visual theory and, in fact, of his whole Commentary on De anima in general is the Jesuit's exceedingly reader-friendly manner of the presentation. Even though Suárez clearly follows the model of the Stagirite's On the Soul, above all his book 2, ch. 7, and his visual theory can be evaluated as Aristotle-oriented, his exposition amounts to first of all a radical systematization of the Stagirite text. Compared with the almost contemporary Coimbran Commentary on De anima, the textual segment of $D A$ VII, 1-5 is a clear systematical enterprise following ordo doctrinae and not model of Aristotle's text. Nowhere in the pertinent parts of the $D A$ VII Suárez's disquisition goes astray in the redundant detail. Everywhere it is obvious where he "stands", which position is advocated by him, and what are his opponents's views. Throughout the text Suárez keeps as distinct the systematical and the exegetical level of his exposition. In a word, the pertinent textual segment, where his theory of visual perception is articulated, manifests that it was prepared by the author as the study support for his students while he was teaching Curso de artes at the Jesuit College in Segovia in the first half of the 1570s.

Even though Suárez's visual theory largely draws on Aquinas's commentaries on Aristotle's On the Soul and On Sense and Sensible Objects, the Jesuit's understanding of light and visual species, as could have been seen from the occasional comparisons with Aquinas, can hardly be considered to be identical with the Angelic doctor's statements. The Jesuit's recurrent claims that the visual species does not receive the (literal) spiritual being in the illuminated translucent medium is anything but the statement, which would be authorized by Aquinas. Suárez's unambiguous emphasis on the physical character of light, which is like colour visible by means of its own species, is also the claim that is difficult to detect in the emphatic way in Aquinas. No doubt, Suárez's explicit addition of lumen to the ambit of the 
total formal object of vision can be seen as the doctrinal consequence of his "naturalistic" concept of light. If any tradition is to be named, with which this aspect of Suárez's visual theory could be linked, it seems to me that it is the tradition of perspectivism. ${ }^{35}$ However, it is not only the Aristotelian heritage and the perspectivist tradition, which determined Suárez's approach. As shown especially in the sections devoted to the intro/ extramissionary account of vision and to the issue of the visual organ, Suárez was very well acquainted with the Galenist tradition as well. As he noted, in anatomical matters the Aristotelian tradition is to be replaced by the up-to-date medical tradition, which was in his exposé represented by the names of Andreas Vesalius and Francisco Vallés.

Last but not least, it must be underlined that Suárez's visual theory can be fully appreciated only within the historical context, which is given by the broad Aristotelian and the renaissance medical tradition. Suárez's "anti-Cartesianism" is evident in his ontology of (true) colours, ${ }^{36}$ which are conceived as permanent qualities inherent in coloured bodies independently of reflection of light. This stand is also palpable in Suárez's swing to the old physics of elements and the primary and secondary (extramental) qualities. All this points to the scientific ethos that is different from that of Descartes and of other exponents of the scientific revolution in the $17^{\text {th }}$ century. Even though from a certain point of view Suárez's emphasis on the material character of the sensible species might have made Descartes's critique of the sensible species easier, it has to be kept in mind that Suárez conceives visual species as disposition and not as figures, which were rightfully caricatured and censured by Descartes in his La dioptrique.

35 For Roger Bacon (1214-1294), the foremost representative of this tradition, the sensible species has only corporeal existence insofar as it requires a material medium within which it subsists. For him the species is also less perfect than the natural corporeal agent. For the corporeality of species in Bacon see Lindberg 1998, lxvi-lxvii. The fact is Suárez does not explicitly refer to Roger Bacon, though. Mostly he refers to perspectivi in general, only sporadically he cites explicitly from Alhazen or Witelo. Clearly, this statement would require a much more in-depth analytical comparison with the abovementioned authors.

36 Suárez admits also the apparent colours, in which perception light is a decisive factor. For the distinction between the true and the apparent (rapidly changing) colours see DA VII, 8, vol. 2, 582-6. 


\section{References}

\section{Primary literature}

Aristotle. 2000. On the Soul, Parva naturalia (incl. On Sense and Sensible Objects), On Breath, edited by Jeffrey Henderson, translated by W. S. Hett. Cambridge, Massachusetts: Harvard University Press.

Descartes, René. 1902. Discours de la méthode \& Essais. Euuvres de Descartes VI, edited by Charles Adam \& Paul Tannery. Paris: Leopold Cerf.

Plato in Twelve Volumes. 1921 (incl. Theaetetus). Vol. 12, translated by Harold N. Fowler. Cambridge, MA: Harvard University Press, London: William Heinemann Ltd.

Plato in Twelve Volumes. 1925. (incl. Timaeus). Vol. 9, translated by W. R. M. Lamb. Cambridge, MA: Harvard University Press, London: William Heinemann Ltd.

Suárez, Francisco. 1981. Commentaria una cum quaestionibus in libros Aristotelis, vol.

2. Edited by Salvador Castellote. Madrid: Editorial Labor.

Sancti Thomae de Aquino. 1888. Opera omnia. Pars Prima Summa Theologiae. A quaestione I ad quaestionem XLIX. Tomus IV. Roma: ed. Leonina.

Sancti Thomae de Aquino. 1984. Opera omnia. Sentencia libri de anima. Tomus XLV, 1. Roma: ed. Leonina.

Sancti Thomae de Aquino. 1985. Opera omnia. Sentencia libri de sensu et sensato. Tomus XLV, 2. Roma: ed. Leonina.

Sancti Thomae de Aquino. 1856. Scriptum super Sententiis. Parma. http://www.corpusthomisticum.org/snp2012.html

Valles, Francisco. 1556. Controversiarum medicarum et philosophicarum libri decem. Compluti: Brocarius.

\section{Secondary literature}

Castellote, Salvador. 1963. "Antropología filosófica en la obra de Francisco de Vallés Covarrubias." Archivo Iberamericano de Historia de la Medicina y Antropología Médica 15: 77-120.

Castellote, Salvador. 1962. Die Anthropologie des Suarez. Freiburg, München: Verlag Karl Alber.

Heider, Daniel. 2015. "Suárezova teorie vzniku species sensibilis a kognitivního aktu vnějších smyslů v kontextu středověké a renesanční filosofie.” Organon F 22/2: 229-249.

Heider, Daniel. 2016a. "Francisco de Toledo, Francisco Suárez, Manuel de Góis and Antonio Rubio on the Activity and Passivity of the External Senses." In Cognitive Psychology in Early Jesuit Scholasticism, edited by Daniel Heider, 38-66. Neunkirchen-Seelscheid: Editiones Scholasticae. 
Heider, Daniel. 2016b. "The Notitia Intuitiva and Notitia Abstractiva of the External Senses in Second Scholasticism: Suárez, Poinsot and Francisco de Oviedo.” Vivarium Vol. 54, Issue 2-3: 173-203.

Heider, Daniel. Forthcoming in 2017. "Late Scholastic Debates About External and Internal Senses: In the Direction of Francisco Suárez (1548-1617)." In Philosophy of Mind in the Late Middle Ages and the Renaissance, edited by Stephan Schmid. Vol. 3 of The History of Philosophy of Mind, edited by R. Copenhaver und C. Shields. London: Routledge.

Hilbert, David R. 2015. “Vision.” In The Oxford Handbook of Philosophy of Perception. Edited by Mohan Matthen, 257-273. Oxford: Oxford University Press.

Lindberg, David C. 1976. Theories of Vision. From Al-Kindi to Kepler. Chicago and London: The University of Chicago Press.

Lindberg, David C. 1998. Roger Bacon's Philosophy of Nature. A Critical Edition, with English Translation, Introduction, and Notes of De multiplicatione specierum and De speculis comburentibus. South Bend, Indiana: St. Augustine's Press.

Knuuttila, Simo. 2008. “Aristotle's Theory of Perception and Medieval Aristotelianism.” In Theories of Perception in Medieval and Early Modern Philosophy. Edited by Simo Knuuttila \& Pekka Kärkkäinen, 1-22. Dordrecht: Springer.

Knuuttila, Simo. 2015. “Suárez’s Psychology.” In A Companion to Francisco Suárez. Edited by Victor M. Salas, and Robert L. Fastiggi, 164-191. Leiden: Brill.

Maier, Anneliese. 1963. “Das Problem der ‘Species Sensibiles in Medio’ und die neue Naturphilosophie des 14. Jahrhunderts.” Freiburger Zeitschrift für Philosophie und Theologie 10: 3-32.

Ross, Peter. 2015. “Primary and Secondary Qualities”. In The Oxford Handbook of Philosophy of Perception, edited by Mohan Matthen, 405-421. Oxford: Oxford University Press.

Siegel, Rudolph E. 1970. Galen on Sense Perception. Basel, New York: S. Karger.

South, James B. 2001. "Suarez and the Problem of External Sensation.” Medieval Philosophy and Theology 10/2: 217-240.

Tachau, Katherine H. 1988. Vision and Certitude in the Age of Ockham. Optic and Epistemology and the Foundations of Semantics 1250-1345. Leiden, New York: Brill. Telkamp, Jörg Alejandro. 2012. "Francisco Suárez on the Intentional Species." Quaestio 12: 3-23.

Tuominen, Miira. 2014. “Sense Perception: Ancient Theories.” In Sourcebook for the History of the Philosophy of Mind, edited by Simo Knuuttila, and Juha Sivola, 39-59. Dordrecht: Springer.

Wolf-Devine, Celia. 1993. Descartes on seeing. Epistemology and Visual Perception. Carbondale and Edwardsville: Southern Illinois University Press.

Yrjönsuuri, Mikko. 2014. "Seeing distance.” In Active Perception in the History of Philosophy. From Plato to Modern Philosophy, edited by José Filipe Silva, and Mikko Yrjönsuuri, 187-206. Dordrecht: Springer. 